\title{
The inverted postnational constellation: Identitarian populism in context
}

\section{Albena Azmanova* (1) | Azar Dakwar* (1)}

\begin{abstract}
As exemplified by the pan-European 'Identitarian movement' (IM), contemporary far-right populism defies the habitual matrix within which right-wing radicalism has been criticised as a negation of liberal cosmopolitanism. The IM's political stance amalgamates features of cultural liberalism and racialist xenophobia into a defence of 'European way of life.' We offer an alternative decoding of the phenomenon by drawing on Jürgen Habermas's 'postnational constellation.' It casts the IM's protectionist qua chauvinistic populism as 'inverted' postnationalism, engendered through territorial and ethnic appropriation of universal political values. As such, inclusionary ideals of cosmopolitan liberalism and democracy purporting humanistic postnationalism have been transformed by Identitarians into elements of a privileged civilisational life-style to be protected from 'intruders.' Remaining within the remit of the grammar of the postnational constellation, trans-European chauvinism, we contend, is susceptible to inclusive articulation. Foregrounding radical emancipatory social transformation would however require not more democracy, but a principled critique of capitalism.
\end{abstract}

\section{1 | INTRODUCTION}

The most recent populist insurrections have not only posed a challenge to the centrist political establishment in Western liberal democracies, they have called into question the very left-right divide that has structured the ideological landscape of these societies for the past two centuries. Far-right anti-establishment formations (such as the French Front national and the Dutch Partij voor de Vrijheid) typically marry an allegiance to liberal values (from freedom of speech to gender equality and LGBT rights) with appeals for social, economic, cultural and physical safety. ${ }^{1}$ The pan-European Identitarian movement (IM), which emerged in the 1960 s and has found a fresh resurgence in the early twenty-first century as the "hipster right", incarnates these peculiarities of contemporary Western populism.

Originally springing up in France and Italy, Identitarians are an increasingly influential exponent in recent ethnocultural transnational right-wing populism which has pervaded, in diverse forms, the entirety of the European 
continent. The IM suggests that Europe's peoples, communities and cultures cohere into a "European way of life"2 that has been ripped apart by the global cosmopolitan and neoliberal turns in the past half-a-century. ${ }^{3}$ At the core of Identitarianism, in both its conceptual and activist-political dimensions, is the tension between national/civilisational identity and neoliberal globalism/cosmopolitanism with all its ramifications and implications. This cleavage is expressed in different ways: some Identitarian currents prioritise a resolute withstanding of "mass immigration" and/ or "Islamisation" in the name of the unique achievements of "Western civilisation" such as liberal values and the welfare state, while others foreground repercussions of an "out-of-control capitalism" that does not pay respect to national boundaries, cultural specificities and communitarian fabrics. ${ }^{4}$

Accordingly, the IM's workings defy the customary diagnosis of "cosmopolitanism vs nationalism" or "clash of civilisations" as sound interpretive framework. Bringing to light the postnational imbrication of Identitarian discourse, we would argue, is crucial for discerning the idiosyncratic nature of contemporary transnational populism. To that end, we find Jürgen Habermas's "postnational constellation" an analytically potent strategy for making sense of the recent recombinant but tensional Identitarian insurrection. Yet, the actual developments of twenty-first-century European right-wing populism strongly suggest that key conceptual tenets of the postnational constellation must be revisited and revitalised if it is to be an adequate cipher of pathological, "inverted" instantiations thereof, as manifested by the IM - which Habermas failed to contemplate and extrapolate. In order to establish the basis for a more adequate postnational analytic, we shall interrogate some common understandings of how "nation", "nationalism", "liberal democracy" and "cosmopolitanism" figure in the current European postnational constellation and correspond with neoliberal capitalistic social relations, thus resulting in inverted forms of postnationalism, rather than facile nationalism or civilisationism. In the process of scrutinising Habermas's conception of the postnational, we outline a different understanding of those configurations and correspondences and, hence, a reinvigorated, emancipatory conception of postnationalism.

\section{2 | THE "HIPSTER" FACE OF CONTEMPORARY POPULISM}

Generation Identity (a.k.a. "hipster right"): young, technologically savvy, cherry pickers of liberal rights (a dose of gender equality, some free speech and freedom of sexual orientation), firmly anti-Muslim, occasionally anti-Semitic, and vehemently anti-immigrant-this youth-based pan-European Identitarian movement unsettles the framework within which far-right populism has been discussed. ${ }^{5}$ The adoption of patriotic rhetoric by many of the anti-establishment insurgencies over the past decade has launched the thesis of the revival of nationalism. Pundits and academics have untiringly presented these outbursts of often incendiary blood-and-soil rhetoric as populist rejections of cosmopolitanism and liberal internationalism, which disenchanted populations are opposing, allegedly in the name of territorial and cultural sovereignty. The diagnosis of hostility to cosmopolitanism as a driver of populism places focus on the nativism that has nourished the familiar, historically available, iterations of nationalism, from patriotism to chauvinism. In other words, we are called on to make sense of the recent swell of populism within the familiar dichotomy of cosmopolitanism versus nationalism.

The demographic profile of the present-day populists gives further texture to the nationalist revival thesis. In contrast to the cosmopolitan elites that they oppose, the populists are reported to be mostly low-skilled, typically

${ }^{2}$ When finalising this article, news broke that the incoming European Commission President Ursula von der Leyen proposed to create a new portfolio in her cabinet titled "Protecting Our European Way of Life", because the EU "must address and allay legitimate fears and concerns about the impact of irregular migration" on its economy and society. President von der Leyen claimed that the European way of life "is built around solidarity, peace of mind and security". BBC, 'EU chief under fire over "protecting way of life" portfolio', 10 September 2019, available at: https://www.bbc.com/news/world-europe49661650 (last accessed 12 September 2019).

${ }^{3}$ J.P. Zúquete, The Identitarians: The Movement Against Globalism and Islam in Europe (University of Notre Dame Press, 2018$)$, at 1-2.

${ }^{4}$ lbid., at 4.

${ }^{5}$ Ibid., at 3. "Generation Identity" is active in Germany, Austria, France, Italy and the UK. Analogues that go by different names exist in these states (e.g. CasaPound in Italy and PEGIDA in Germany), and virtually all other European states. H. Handler, 'European Identity and Identitarians in Europe' (2019) SSRN Electronic Journal 5, 7. https://doi.org/10.2139/ssrn.3338349 (last accessed 15 September 2019). 
middle-aged, culturally conservative men without a college education, employed in the old industrial sectors of the economy who have seen their livelihoods threatened by automation and globalisation. However, the well-educated, technologically savvy and well-employed members of the "patriotic youth movement that promotes the values of homeland, freedom and tradition" (in Generation Identity's self-portrayal), ${ }^{6}$ cannot be comfortably viewed as a rejection of transnationalism by the ageing losers of neoliberal economic integration and disruptive technological innovation.

This movement of "native Europeans who have long been forgotten by the establishment" (again, in their own description) seems to fit well an alternative, equally popular interpretative framework within which right-wing populism tends to be discussed nowadays, on the grounds of its anti-Muslim and anti-Arab sentiment-along the lines of popular instantiations of Samuel Huntington's "clash of civilisations" thesis. According to it, the old ideological competition between the left and the right, as well as the conflicts among nations, are being replaced by radical cultural conflicts. Civilisations, representing the highest rank of cultural identity, are the main protagonists in the new historical drama. Right-wing populism in Western liberal democracies, by this account, strives to mobilise the Western, Judeo-Christian civilisation against the Muslim world. ${ }^{7}$ However, on closer inspection, the populism of the early twenty-first century is a poor fit for this matrix of interpretation. Far from the hostility that marks the "clash of civilisations" stand-off, the IM endorses ethno-pluralism-aspiring for "a world of plurality, peoples and cultures" in which populations coexist in a "separate but equal" modus vivendi, in contrast to the intra-cultural diversity preferred by liberal cosmopolitans. Rather than the belligerent posture of the "clash of civilisations" thesis, the IM preaches not confrontation, but humanitarian and developmental assistance to civilisational rivals-to "support regional development work for countries shaped by war and poverty, helping people to remain in and develop their own homelands". 8

Evidence from other forms of combative populism, such as the Gilets Jaunes protests in France or the Five Star movement in Italy, further defies the two prevailing explanatory frameworks which rely on a nativist-versus-cosmopolitan dichotomy and a clash of civilisations diagnosis. While unashamedly populist and often anti-EU in their rhetoric, these movements are pro-European, and place cost of living and good governance grievances (the privileges and corruption of ruling elites) at the centre of their mobilisations. Whenever an anti-foreigner or anti-immigrant sentiment perspires, analysts tend to unpack its sources in culturalist terms. However, this is belied by the economic triggers of xenophobia-fear of loss of sources of livelihood as a result of job outsourcing to countries of cheap labour or to immigrants ready to take on jobs for a fraction of the official remuneration, thereby triggering social dumping. ${ }^{9}$ Prominent among such discourses is a concern with the quality of democracy and the heritage of the welfare state, including the scope of and access to social rights. Thus, what the ostensibly protectionist-cum-culturalist discourse of nationalism masks is a collective identity sourced from a shared attachment to a "European way of life", central to which are the values of popular sovereignty, accountable rule, economic security and social rights.

\section{3 | HABERMAS'S POSTNATIONAL CONSTELLATION}

With the challenge they pose to the two dominant explanatory frameworks, the pan-European IM, as well as the economic xenophobia and the "democratic" quest of the national-populist insurgencies, mandate us to seek an

\footnotetext{
${ }^{6}$ Generation Identity (United Kingdom and Ireland) web platform, available at: https://www.generation-identity.org.uk/ (last accessed 1 July 2019). The Identitarians reject all association with the Third Reich or National Socialism. The German intelligence service has classified the German section as a rightwing extremist entity. 'Identitäre Bewegung ist eindeutig rechtsextremistisch', Zeit Online, 11 July 2019, available at: https://www.zeit.de/politik/ deutschland/2019-07/verfassungsschutz-identitaere-bewegung-rechtsextremismus-einstufung (last accessed 10 September2019).

7In Huntington's account, Western civilisation rests on the Catholic and Protestant forms of Christianity only (Western Christendom), excluding Muslim and Christian Orthodox peoples. S. Huntington, The Clash of Civilizations and the Remaking of World Order (Simon \& Schuster, 1996), at 155-179. However, over the last two decades the thesis has been popularised as one of hostile confrontation between the Western civilisation as rooted in Judeo-Christian values, and the Muslim civilisation. R. Brubaker, 'Between Nationalism and Civilizationism: The European Populist Moment in Comparative Perspective' (2017) 40 Ethnic and Racial Studies, 1211-1212.

${ }^{8}$ Generation Identity web platform, above, n. 6.

${ }^{9}$ For the notion of "economic xenophobia" as a distinctive feature of current-day populism, see A. Azmanova, 'Against the Politics of Fear: On Deliberation Inclusion, and the Political Economy of Trust' (2011) 37 Philosophy and Social Criticism, 401.
} 
alternative, analytically more potent, conceptual strategy for making sense of the current populist upheavals. Such strategy is effectively offered by the notion of the "postnational constellation", as formulated by Jürgen Habermas in the late 1990s. We will suggest that, despite the nationalist and exclusivist rhetoric, the recent rise of populism in Europe can be understood as a pathological incarnation of what Habermas had diagnosed, as well as welcomed, as a transition to a postnational form of collective political life. What is now mistakenly diagnosed as a failure of the postnational transformation and the resurrection of an antecedent form of political identity (i.e., populist-nationalism) is in fact an inverted postnationalism. On the one hand, it retains many features of the postnational constellationattachment to universal values such as democracy, accountable rule and basic social rights. On the other hand, it transfigures these by confining them to a bounded territorial locus (the nation-state, the European Union, etc.) and setting an exclusionary political dynamic where these values are to be defended from "non-native" citizens and foreign "intruders".

In other words, the populism of the twenty-first century can only make sense as a pathology of the postnational state of the political. This is an inverted postnationalism that is created through a territorial and ethnic appropriation (and ergo, de-universalisation and de-transcendentalisation) of universal political values. We will next offer an account of Habermas's notion of the "postnational constellation" in order to display both its capacity to host a critique of trans-European chauvinism and its failure to foresee its inversion effected from within its grammar.

Habermas develops the notion of a postnational political collectivity in opposition to both the territorial "somewhere" of a nation-state and the nebulous "nowhere" of cosmopolitanism as abstract humanism, to borrow David Goodhart's clever pair of concepts. ${ }^{10}$ The postnational constellation is not a theoretical construct developed in celebration of the declining relevance of the nation-state in the context of global integration. The fact of this declining relevance Habermas sees as an emancipatory opening enabling the overcoming of the nativist and exclusionary instantiations of politics that have beset modernity, in the direction of the humanist redemption to which the critical social theory of Frankfurt School origin has been committed. ${ }^{11}$

Habermas holds that the "national consciousness is a specifically modern manifestation of cultural integration. ${ }^{12}$ As this form of integration is irrational and proceeds through acts of exclusion, the emancipatory project necessitates the articulation of an alternative, principled and inclusionary basis of cultural integration. Habermas finds the grains of the emancipatory move in the fact that the nation is oscillating "between the imaginary organicity of a Volksnation and the legal construct of a nation of citizens." ${ }^{13}$ Ascribed national identity and the acquired democratic citizenship are the two core ingredients of republican citizenship, as it developed after the bourgeois revolutions of the eighteenth century. At the end of the nineteenth century, Habermas observes, the conditional relation between these two elements could even be reversed to a point when "the nation of citizens finds its identity not in ethnic and cultural commonalities but in the practice of citizens who actively exercise their rights to participation and communication. ${ }^{14}$ It is in this shift from the seemingly organic commonality of a nation to a community of democratic citizenship that the emancipatory trajectory of the emergent postnational constellation resides.

Habermas proposes to solve the residual contradiction between the particularism of national identity and the universalism of subjective rights by means of the idea of "constitutional patriotism". He avers that even when collective life is enacted within the realm of territorial democracy, shared identity is to be attached to non-territorial values of constitutionalism and democratic rights. Constitutional patriotism is the essentialisation of this new collective

\footnotetext{
${ }^{10}$ Analysing the Brexit vote, David Goodhart has observed that the key political division has been between the "somewheres" and the "nowheres". D. Goodhart, The Road to Somewhere: The Populist Revolt and the Future of Politics (C. Hurst \& Co., 2017).

${ }^{11}$ Dirk Moses describes Habermas's position as "redemptive republicanism" because it is driven by a desire to free the German political identity from associations with pre-WWII German nationalism. D. Moses, German Intellectuals and the Nazi Past (Cambridge University Press, 2007$)$, at 121.

${ }^{12}$ J. Habermas, Between Facts and Norms: Contributions to a Discourse Theory of Law and Democracy (Polity, 1996 ), at 493.

${ }^{13} \mathrm{~J}$. Habermas, The Postnational Constellation: Political Essays (MIT Press, 2001), at 101-102.

${ }^{14}$ Habermas, above, n. 12 , at 495.
} 
identity-the tangible collective consciousness appropriate for contemporary nation-states seeking to inspire rational loyalty to egalitarianism and liberal democracy on the part of their citizens. ${ }^{15}$

Eventually, the postnational constellation emerges as a multi-layered global order, comprising an inclusive basis of solidarity within the nation-state, the development of new transnational forms of political community such as the European Union beyond the nation-state, and the augmentation of international law and institutions regulating relations between states and guaranteeing human rights at the global level. Habermas sees this complex edifice not only as a desirable idea for the future but also as a tangible social reality in the third millennium. ${ }^{16}$ Importantly, the emancipatory dynamics of the emergent postnational condition of the political are sourced not so much from an allegiance to the fiction of a juridified cosmopolitan world society as from a shift in the normative content of citizenship. This is a shift in the very grounds of collective cultural identity from a jus sanguinis and introverted territorial and statist approach to political belonging to universal political notions of citizenship and political community nourished by the norms and practices of liberal democracy. A backdrop of national consciousness remains fundamental for harbouring the ethos of constitutional patriotism, which aims essentially at bridging the gap between shared attachments towards universalistic principles and the actualisation of these principles through particular national institutions. ${ }^{17}$ In sum, in the postnational constellation, the nation qua cosmopolitan political community, is generated through imaginary solidarity among culturally-particular human beings forging albeit brittle bonds of reasoned communication and cooperation enabled through the juridified norms of liberal constitutionalism and democracy, which they internalise as their shared ethos.

\section{INVERTED POSTNATIONALISM}

What are the conditions of possibility of Habermas's postnational constellation? On the one hand, it is the historical movement of persistently shifting the cultural basis of collective identity from the imaginary organicity of a Volksnation to the inclusionary values of democratic citizenship. On the other hand, Habermas sees the emergence of the postnational order as fostered, among others, by what he deems as a Janus-faced reality of neoliberal globalisation. While essentially eroding the rudimentary social capital, trust and solidarity so essential for domestic societies' overall welfare, neoliberal politics have generated a demand for democratic accountability beyond the nationstate. In other words, global market integration would necessitate a corresponding system of global political accountability.

The recent upsurge of populism and the emergence of trans-European chauvinism confirm, as much as disprove, the thesis of the emergent postnational constellation. These mobilisations have appropriated the rhetoric of constitutional patriotism as they are pledging allegiance to democracy, rule of law and basic freedoms, and are eager to safeguard the achievements of the welfare state. At the same time, they have eviscerated the normative spirit of postnationalism with their recourse to exclusionary protectionist claims: "our" democracy, "our" capitalism, "our" welfare state. ${ }^{18}$ Thus, the inclusionary ideals of cosmopolitan liberalism and democracy that were meant to nourish the advent of humanistic postnationalism have been transformed into goods to be distributed, elements of a privileged life-style to be protected from "intruders".

The shift from the seemingly organic national community to the universalism of subjective rights that was supposed to engender the humanistic postnationalism Habermas had in mind has not simply been arrested or reversed. The postnational constellation, as expressed for example by Generation Identity, has been inverted-the cultural basis of the collective identity the new populist movements mobilise is effectively drawn from ideas of democratic citizenship and liberal constitutionalism, but these elements are rearticulated into a territorial, foreclosed,

\footnotetext{
${ }^{15}$ Habermas, above, n. 13 , at 74.

16. Habermas, Europe: The Faltering Project (Polity, 2009).

${ }^{17} \mathrm{~J}$. Habermas, The Inclusion of the Other: Studies in Political Theory (MIT Press, 1998), at 114-120; and Habermas, above, n. 13, at 108-112.

${ }^{18}$ R. Brubaker, 'Why Populism?' (2017) 46 Theory and Society, 366, 371-372.
} 
exclusionary idea of belonging, wrapped as civilisational posture. Just like the socially engineered fiction of the nation had transformed into a seemingly organic community in the collective imaginary of nationalism, currently the norms of liberal democracy and the achievements of the welfare state are being claimed as exclusive properties of a seemingly organic community of a Western/European collective identity. ${ }^{19}$

Habermas correctly contends that the driving force for integration in the postnational European society is not to be catered by the substrate of a supposed "European people". Instead, he puts his faith in the emancipatory import of "the communicative network of a European-wide political public sphere embedded in a shared political culture." ${ }^{20}$ As it turns out, however, the IM and its siblings are actively instrumentalising these very communicative networks for driving an inverted postnationalism that keeps supplying disfigured liberal cosmopolitanism.

Why has the transition towards the postnational been subverted in this way? Despite being steeped in the empirical reality of the advancement of (neo)liberal democracy and the transnationalisation of economic interactions, it could be that Habermas's diagnosis of immanent tendencies towards the felicitous condition of inclusive cosmopolitanism has been overly optimistic. He sees the articulation of the postnational constellation as a historical tendency of progressive inclusion, transforming the self-ascribed singularity of the nation into an egalitarian form of collective self-identification through the inclusive political values of liberal democracy. On this basis he foretells 'the end of the symbiosis between the constitutional state and 'the nation' as a community of shared descent, and a renewal of a more abstract form of civil solidarity in the sense of a universalism sensitive to difference." 21

Habermas does acknowledge the remaining pernicious propensities in the modern European nation, as it has "inherited the power to generate stereotypes from the older, pre-political concept of the nation as an index of descent and origin", which became "allied with antisemitism, with disastrous consequences." 22 He nevertheless believes that anchoring more firmly collective identity in the political values of democratic citizenship and liberal constitutionalism (a process that began with the bourgeois revolutions of the eighteenth century), would liberate cultural identity from the irrationality of national identity. In this way, the cultural can be salvaged and distilled from the national in a way that makes the latter redundant. This optimism is rooted in a highly positive interpretation of capitalist modernity. Already in his early monograph The Structural Transformation of the Public Sphere (1962), Habermas maintained that the rational universal kernel of bourgeois social practice has achieved epistemic breaks with premodern forms of irrationality; that the bourgeois public sphere, which he sees as constituted by ideas of equal citizenship, themselves conditioned by an egalitarian universalism, has, therefore, a strong emancipatory effect, as articulated in the ideas of popular sovereignty and human rights. ${ }^{23}$ In his account, "the 'bourgeoisie' in the liberal nationstate of the early modern period developed-along with their specific modes of oppression and exclusion-models of self-administration and participation, of freedom and tolerance, that expressed the spirit of bourgeois emancipation." ${ }^{24}$

Around the same time Habermas advanced his above-mentioned thesis on the bourgeois rationality, Theodor Adorno had observed that, despite their pledge to humanistic universalism, bourgeois revolutions "all have an element of illusion, of ideology, about them." ${ }^{25}$ He noted that "rationality" is a concept based on an understanding of "the self-preservation of the individual" and that bourgeois notions of freedoms and rights remain limited by this conception of the rational as self-preservation. ${ }^{26}$ Most importantly, the irrational, Adorno remarked, is neither a residue from older forms of collective identity, nor is it inadvertent: "the irrational elements in developed rational bourgeois society are not coincidental, but essential. Ends-means rationality predominates, but the ends, the

\footnotetext{
${ }^{19}$ Habermas, The Inclusion of the Other, above, n. 17.

${ }^{20}$ Habermas, The Inclusion of the Other, above, n. 17, at 153.

${ }^{21}$ Habermas, above, n. 13 , at 84.

${ }^{22}$ Habermas, The Inclusion of the Other, above, n. 17, at 107, 110-111.

${ }^{23} \mathrm{~J}$. Habermas, The Structural Transformation of the Public Sphere: An Inquiry into a Category of Bourgeois Society (Polity, 1989).

${ }^{24}$ Habermas, above, n. 13, at 83-84.

${ }^{25}$ T.W. Adorno, History and Freedom: Lectures 1964-1965 (Polity, 2006), at 35.

${ }^{26}$ Ibid., at $4,41$.
} 
organisation as a whole, remain irrational. This explains the persistence of irrational institutions such as the nation and the family." ${ }^{27}$ Thus, the more inclusive the Volksnation became, the more imminent the hold of the modern, allegedly rational-scientific, concept of race and dynamic of racialisation became, Adorno observes. The movement of inclusion implied in the horizontal integration of the nation, he argued, is countered by an immanent movement of vertical racialising exclusion, which is modern and unavoidable rather than pre-modern and aberrant or collateral. ${ }^{28}$ Recent history has manifested the cogency of Adorno's account.

Herein lies the deficiency of Habermas's postnational prognosis. While Adorno held that the toxic irrationality of racism and xenophobia, which are touted as unintended by-products of protectionist rationalism, is endemic to bourgeois society, to capitalism as the instrument of the reproduction of bourgeois individuals as a class, Habermas retained faith in the emancipatory promise of capitalist modernity by altering the status of capitalism within his social ontology. In his account, capitalism is no longer an overarching system of social relations (as it had been in the analysis of the first generation of Frankfurt School authors), but an economic subsystem. Despite taking a Marxian account of capitalism as social formation as his point of departure, his critique of "late capitalism" in Legitimation Crisis (1973) gets articulated in the terms of systems theory, drawing on Talcott Parsons and Niklas Luhmann. ${ }^{29}$ Within this ontology, society is to be conceived as a unity of economic, administrative, sociocultural and legitimation systems; capitalism is viewed no longer as a comprehensive social order, but as a domain of value-neutral instrumental rationality deployed in the production of wealth, and which can be oriented towards human values under conditions of substantive democracy-i.e., genuine participation of citizens in the process of discursive political will-formation. ${ }^{30}$ Solutions to social harm emerge within the remit of political institutions (building up democracy) rather than in the remit of the political economy (demolishing capitalism). One such solution is the postnational constellation.

As Habermas sets aside Adorno's cautioning against over-reliance on the emancipatory potentiality of capitalist modernity, he overlooks the possibility that the postnational-cum-cosmopolitan gets entrapped in the irrational energies of bourgeois aspirations and capitalism. These energies persistently de-transcendentalise the inclusionary promise of the "rational" political edifice of liberal democracy into an introverted drive of self-preservation.

\section{5 | CONCLUSION}

If it is true, as we have argued, that the populist mobilisations still inhabit the postnational constellation but are its faulty, inverted articulations, the potential for a positive, redemptive articulation is still available. The enabling conditions for such a corrective articulation have to do with the socio-economic circumstances of stable and secure livelihoods; obtaining these conditions would necessitate opposing capitalism's dynamics of competitive production of profit which destabilises livelihoods and proliferates a dynamic of racialist exclusion, triggering noxious political instincts and practices. ${ }^{31}$ Unfortunately, Habermas's detailed articulation of the postnational constellation has very little room for critique of capitalism. Even when invoking the disastrous consequences of unbridled global financial capitalism in his more recent writings, he still thinks in terms of taming the thrust and offsetting the externalities generated by its modus operandi via strengthening democracy and liberal constitutionalism. ${ }^{32}$

Protectionist qua chauvinistic populism, we argued, has thrived on the postnational constellation by inverting it, yet remaining within its remit. Its defeat, if it is to come in a democratic form, would require reviving the emancipatory potentialities latent in inverted postnational lifeforms. But to activate that potential, social criticism would need

\footnotetext{
${ }^{27} \mathrm{He}$ continues, "[b]ecause the theory as a whole is not transparent, not compatible with the principle of rationality, the citizen always has a bad conscience when he operates with such concepts. Hence the rancour and rage in the concept of the nation, something that is perpetuated in the Eastern bloc countries, where "cosmopolitanism" is a term of abuse." Ibid., at 104.

${ }^{28}$ Ibid., at 103-104.

${ }^{29} \mathrm{~J}$. Habermas, Legitimation Crisis (Beacon Press, 1975).

${ }^{30}$ A. Azmanova, 'Late Capitalism', in A. Allen and E. Mendieta (eds.), The Cambridge Habermas Lexicon (Cambridge University Press, 2019 ), at 230.

${ }^{31}$ A. Azmanova, Capitalism on Edge (Columbia University Press, 2020).

${ }^{32}$ J. Habermas, The Crisis of the European Union - A Response (Polity, 2012), at xi, 35-36; and J. Habermas, The Lure of Technocracy (Polity, 2015), at vii.
} 
a principled and stronger dose of critique of capitalism as a system of social relations constituted by the dynamics of capital accumulation, rather than as an economic sub-system busy with the creation of affluence. For if the culprit for the demise of cosmopolitan democracy is capitalism, the remedy for the affliction cannot be more democracy, but charting a postnational path for the eradication of capitalism.

\section{ORCID}

Albena Azmanova (D) https://orcid.org/0000-0002-2471-2016

Azar Dakwar (D) https://orcid.org/0000-0003-0269-3632

How to cite this article: Azmanova A, Dakwar A. The inverted postnational constellation: Identitarian populism in context. Eur Law J. 2019;25:494-501. https://doi.org/10.1111/eulj.12342 